\title{
SUBTITUSI DEDAK PADI OLEH POD KAKAO YANG DIFERMENTASI Aspergillus niger DALAM RANSUM TERHADAP KARKAS DAN ORGAN DALAM AYAM BROILER
}

\section{(The Substitution of Rice Bran by Cocoa Pod Fermented with Aspergillus niger in Diet on Carcass and Internal Organs of Broiler Chickens)}

\author{
Harmonista Tarigan', Ade Trisna ${ }^{2}$ dan Ma'ruf Tafsin ${ }^{2}$ \\ 1. Mahasiswa program Studi Peternakan Fakultas pertanian Universitas Sumatera Utara \\ 2. Staf Pengajar program Studi Peternakan Fakultas pertanian Universitas Sumatera Utara
}

\begin{abstract}
This research aimed to study the rice bran substitution by cocoa pod fermented by Aspergillus niger on carcass and internal organs of broiler. The study was conducted at the Laboratory Animal Sciences Faculty of Agriculture University of Sumatera Utara. This study used completely randomized design with 6 treatments and 4 replications. The treatments that used were ROa (commercial feed) and ratio of the substitution rice bran with pod cocoa fermented $R 0 b$ (100:0), $R 1$ (75:25), R2 (50:50), R3 (25:75), $R 4$ (0:100). The variables were measured consist of slaughter weight, carcass, carcass percentage, relative weight of gizzard, liver, abdominal fat, length of duodenum, jejenum, illeum, caecum. The results show that the rate of substitution of cocoa pod by rice bran gave highly significant different $(P<0.01)$ on decreasing the slaughter weight, carcass weight and carcass percentage, but it gave an increasing in the length of the small intestine and colon. Substitution rate of rice bran by cocoa pod showed non significantly effect $(P>0.05)$ on relative gizzard weights, relative liver weight and abdominal fat. It can be concluded that the cocoa pod can be used to replace rice bran as much as $50 \%$ of the $12 \%$ proportion of rice bran in broiler rations
\end{abstract}

Keywords : Cocoa Pods, Aspergillus niger, carcass, internal organs, broiler chickens

\begin{abstract}
ABSTRAK
Penelitian ini bertujuan untuk menguji tingkat penggunaan subtitusi dedak padi oleh pod kakao yang difermentasi dengan Aspergillus niger terhadap karkas dan organ dalam ayam brioler. Penelitian dilakukan di Laboratorium Biologi Ternak Program Studi Peternakan USU. Penelitian ini menggunakan rancangan acak lengkap dengan 6 perlakuan dan 4 ulangan. Perlakuan yang digunakan adalah yaitu R0a (pakan komersil), R0b (100:0), R1 (75:25), R2 (50:50), R3 (25:75), R4 (0:100). Peubah yang diamati adalah bobot potong, karkas, persentase karkas, bobot relatif empedal, panjang duodenum, jejenum, illeum, caecum, rektum, bobot relatif hati dan bobot relatif lemak abdominal. Hasil penelitian menunjukkan bahwa tingkat subtitusi dedak padi oleh pod kakao memberikan pengaruh yang berbeda sangat nyata $(\mathrm{P}<0,01)$ terhadap penurunan bobot potong, bobot karkas dan persentase karkas tetapi memberikan peningkatan terhadap panjang usus halus dan usus besar. Tingkat subtitusi dedak padi oleh pod kakao tidak menunjukkan pengaruh nyata terhadap $(\mathrm{P}>0,05)$ bobot relatif empedal, bobot relatif hati dan lemak abdominal. Dapat disimpulkan bahwa pod kakao dapat digunakan untuk menggantikan dedak padi sebanyak $50 \%$ dari $12 \%$ proporsi dedak padi dalam ransum ayam broiler.
\end{abstract}

Kata kunci : Pod kakao, Aspergillus niger, karkas, organ dalam, ayam broiler

\section{PENDAHULUAN}

Peternakan merupakan sektor penyumbang terbesar dalam penyediaan kebutuhan pangan khususnya kebutuhan protein hewani. Kebutuhan protein hewani semakin lama semakin meningkat, seiring dengan pertambahan dan meningkatnya kesadaran masyarakat akan pentingnya zat gizi. Ayam broiler dapat dipilih sebagai salah satu alternatif dalam upaya 
pemenuhan protein asal hewani karena ayam broiler memiliki pertumbuhan bobot badan yang sangat cepat. Ayam broiler dapat memenuhi selera konsumen atau masyarakat karena daging ayam broiler sangat empuk dan enak selain itu harganya terjangkau oleh masyarakat karena relatif murah. Beternak ayam broiler dapat dilakukan dengan modal yang kecil atau dengan modal yang besar, sebagai usaha sambilan ataupun sebagai usaha pokok. Siklus hidup ayam broiler relatif pendek, sangat efisien dalam menggunakan bahan pakan maka akan cepat pula mengatasi tingginya permintaan daging (Murtidjo, 1987).

Salah satu bahan penyusun ransum ayam yang paling dibutuhkan adalah dedak padi. Perkembangan penduduk dan makin sempitnya areal pertanian, menyebabkan ketersedian dedak padi kian menipis, yang berakibat pada kenaikan harga dedak padi yang cukup tinggi.

Hal tersebut diatas telah menjadi kendala dalam upaya peningkatan dan pengembangan usaha peternakan, dimana kurang tersedianya sumber pakan dengan harga yang terjangkau dalam jumlah kontinyu, mengingat biaya pakan yang paling besar yaitu $60-70 \%$ dari total biaya produksi. Efisiensi penggunaan pakan berarti meningkatkan nilai tambah usaha peternakan. Salah satu cara pemecahannya adalah dengan mencari pakan alternatif. Hasil samping pertanian atau perkebunan memiliki potensi untuk digunakan sebagai pakan alternatif untuk ternak seperti hasil samping dari perkebunan kakao.

Menurut data BPS (2010) luas perkebunan kakao Sumatera Utara adalah 59.370,90 ha dengan produksi mencapai 36.289,78 ton. Umumnya buah kakao (Theobroma cacao) setelah dipanen buahnya dikupas dikebun dan isinya (27\%) diangkut ke pabrik untuk diolah, sedangkan bagian cangkangnya atau pod kakaonya (73\%) biasanya disebarkan di sekitar tanaman (Darwis et al., 1988). Melihat potensi tersebut yaitu ketersediaan yang jumlahnya melimpah, murah dan tidak bersaing dengan manusia serta mengandung nutrisi yang dibutuhkan oleh ayam broiler, maka pod kakao layak digunakan sebagai sumber pakan alternatif, namun terkendala oleh kandungan serat kasar yang tinggi. Teknologi fermentasi dapat digunakan untuk mengatasi kendala tersebut, sehingga meningkatkan manfaatnya sebagai pakan ternak.

Fermentasi pakan dengan memanfaatkan Aspergillus niger dapat memperbaiki sifatsifat tertentu dari suatu bahan menjadi lebih mudah dicerna, lebih tahan disimpan dan dapat menghilangkan senyawa racun yang dikandungnya (Saono, 1998). Senyawa racun dalam pod kakao adalah teobromin yang merupakan zat anti nutrisi. Kandungan nutrisi pod kakao sebelum fermentasi adalah bahan kering 89,40\%, protein kasar 7,35\%, lemak kasar 1,42\%, serat kasar 33,10\% dan abu 9,89\% (Siregar, 2009). Kandungan nutrisi pod kakao yang telah 
difermentasi adalah bahan kering $83,40 \%$, energi metabolis $1.767,86 \mathrm{Kkal} / \mathrm{kg}$, protein kasar $12,89 \%$, lemak kasar 2,96\%, serat kasar 21,50\% dan abu 9,05\%.

Nataamidjaya, et al., (1995) menyatakan bahwa karkas sangat erat kaitannya dengan bobot badan, pertambahan bobot badan dipengaruhi oleh pakan penyusun ransum. Penyerapan nutrisi pakan dalam tubuh berhubungan dengan ukuran organ dalam. Pod kakao fermentasi sebagai salah satu bahan penyusun ransum diharapkan bisa menaikkan pertambahan bobot badan. Dengan meningkatnya bobot badan maka karkas juga akan mengalami kenaikan.

Berdasarkan uraian diatas, timbul pemikiran untuk meneliti pemanfaatan pod kakao yang difermentasi dengan Aspergillus niger sebagai bahan penyusun ransum dalam menunjang pertumbuhan ayam broiler.

\section{BAHAN DAN METODE PENELITIAN}

\section{Lokasi dan Waktu Penelitian}

Penelitian ini dilaksanakan di Laboratorium Biologi Ternak Program Studi Peternakan Fakultas Pertanian Universitas Sumatera Utara, Medan, Jl. Prof. Dr.A.Sofyan No.3 dengan ketinggian $25 \mathrm{~m}$ diatas permukaan laut. Penelitian dilaksanakan selama 6 minggu dimulai dari Juli-Agustus 2012.

\section{Bahan dan Alat Penelitian}

Day old chick (DOC) yang digunakan sebagai objek penelitian sebanyak 120 ekor strain Cobb - LH 500 dengan rata-rata bobot awal sekitar 43,7 \pm 2,07 g. Bahan pakan penyusun ransum terdiri atas tepung jagung, dedak padi, bungkil kelapa, bungkil kedelai, tepung ikan, minyak nabati, tepung kulit buah kakao fermentasi, kapur dan top mix. Air minum untuk memenuhi kebutuhan air dalam tubuh diberikan secara ad libitum. Air gula untuk mengurangi stress dari kelelahan selama transportasi. Rodalon sebagai desinfektan kandang dan peralatan baik tempat pakan maupun tempat minum. Vaksin ND 5 Ma Clone ${ }^{\circledR}$ diberikan pada umur 4 hari melalui tetes mata, IBD ${ }^{\circledR}$ diberikan pada umur 14 hari melalui air minum dan ND Lasota ${ }^{\circledR}$ diberikan pada umur 18 hari melalui air minum untuk memberikan kekebalan terhadap tubuh ayam broiler. Formalin $40 \%$ dan $\mathrm{KMnO}_{4}$ (kalium permanganat) untuk fumigasi kandang. Kapang Aspergillus niger sebagai bahan fermentasi kulit buah kakao. Vitamin seperti vitachick ${ }^{\circledR}$ diberikan melalui air minum sebagai suplemen tambahan. 
Alat yang digunakan adalah kandang baterai berukuran $100 \mathrm{~cm}$ x $100 \mathrm{~cm} \times 50 \mathrm{~cm}$, jumlah kandang sebanyak 24 unit dan tiap unit di isi 5 ekor DOC, peralatan kandang terdiri dari 24 unit tempat minum dan 24 unit tempat pakan, timbangan salter dengan kapasitas $5 \mathrm{~kg}$ dengan ketelitian 0,01 g untuk menimbang pertambahan bobot badan ayam, alat penerangan dan pemanas berupa lampu pijar 40 watt sebanyak 24 buah, Thermometer sebagai alat untuk mencatat suhu ruangan, alat pembersih kandang (sapu, sekop, hand sprayer dan lainnya), pisau, plastik, ember, thermometer sebagai alat pengukur suhu, alat tulis, buku data dan kalkulator. Terpal dengan ukuran 3 × 6 m sebanyak 4 buah sebagai penutup dinding ruangan.

\section{Metode Penelitian}

Adapun rancangan penelitian yang digunakan adalah rancangan acak lengkap (RAL) yang terdiri atas 6 perlakuan dan 4 ulangan dan setiap ulangan terdiri atas 5 ekor broiler. Perlakuan yang diteliti adalah :

$\mathrm{R}_{0 \mathrm{a}} \quad=$ Pakan komersil (Kontrol)

$\mathrm{R}_{0 \mathrm{~b}} \quad=$ Rasio subtitusi dedak padi dengan pod kakao $(100: 0)$ dalam ransum

$\mathrm{R}_{1} \quad=$ Rasio subtitusi dedak padi dengan pod kakao $(75: 25)$ dalam ransum

$\mathrm{R}_{2}=$ Rasio subtitusi dedak padi dengan pod kakao $(50: 50)$ dalam ransum

$\mathrm{R}_{3} \quad=$ Rasio subtitusi dedak padi dengan pod kakao $(25: 75)$ dalam ransum

$\mathrm{R}_{4}=$ Rasio subtitusi dedak padi dengan pod kakao $(0: 100)$ dalam ransum

Model matematik percobaan yang digunakan adalah :

Yij $\quad=\mu+\sigma \mathbf{i}+€ \mathbf{i j}$

Keterangan:

$\mathrm{i} \quad=1,2,3, \ldots \mathrm{i}=$ perlakuan

$\mathrm{j} \quad=1,2,3, \ldots \mathrm{j}=$ ulangan

Yij = nilai pengamatan pada perlakuan ke-i, ulangan ke-j

$\mu \quad=$ nilai tengah umum

бi = pengaruh perlakuan ke-i

$€ \mathrm{ij} \quad=$ efek $\mathrm{j}$ galat pada perlakuan ke-i, ulangan ke-j 
Tabel 1. Kandungan nutrisi kulit buah kakao tanpa fermentasi dan kulit buah kakao yang difermentasi dengan Aspergillus niger

\begin{tabular}{lll}
\hline Nutrisi & Kulit buah Kakao & Kulit buah Kakao fermentasi \\
\hline Bahan kering (\%) & $89,40^{\mathrm{a}}$ & $83,70^{\mathrm{b}}$ \\
Energi metabolis (Kkal/kg) & - & $1767,86^{\mathrm{c}}$ \\
Protein kasar (\%) & $7,35^{\mathrm{b}}$ & $12,89^{\mathrm{b}}$ \\
Lemak kasar (\%) & $1,42^{\mathrm{a}}$ & $2,96^{\mathrm{b}}$ \\
Serat kasar (\%) & $33,10^{\mathrm{a}}$ & $21,50^{\mathrm{b}}$ \\
Abu (\%) & $9.89^{\mathrm{a}}$ & $9,05^{\mathrm{b}}$ \\
\hline Sumber: & ${ }^{a}$ Siregar(2009) & \\
\multicolumn{2}{c}{ Laboratorium Nutrisi dan Pakan Ternak FP USU (2011) } \\
\multicolumn{2}{c}{ Loka Penelitian Kambing Potong Sei Putih (2011) }
\end{tabular}

\section{Susunan ransum}

1. Periode Starter

Tabel 2. Formula dan Kandungan Nutrisi Ransum Periode Starter

\begin{tabular}{lllllll}
\hline Komposisi pakan & R0a & R0b & R1 & R2 & R3 & R4 \\
\hline T.Jagung & & 47 & 47,1 & 47,1 & 47 & 47 \\
T.Ikan & & 10 & 10 & 10 & 10 & 10 \\
B.kedelai & & 25,3 & 25,2 & 25,2 & 25,2 & 25,2 \\
Dedak padi & & 12 & 9 & 6 & 3 & 0 \\
P. Kakao F & & 0 & 3 & 6 & 9 & 12 \\
Kapur & & 1 & 1 & 1 & 1 & 1 \\
Top Mix & & 0,7 & 0,7 & 0,7 & 0,8 & 0,8 \\
M. Nabati & & 4 & 4 & 4 & 4 & 4 \\
\hline Total & & 100 & 100 & 100 & 100 & 100 \\
\hline Kandungan Nutrisi & & & & & & \\
PK & 22 & 22,01 & 22,01 & 22,04 & 22.06 & 22.09 \\
EM & & 3051,05 & 3052,52 & 3053,21 & 3050,53 & 3051,22 \\
SK & mak4 & 3,57 & 3,91 & 4,26 & 4,6 & 4,94 \\
LK & min5 & 4,29 & 4,02 & 3,74 & 3,74 & 3,19 \\
Ca & 1 & 1,13 & 1,12 & 1,12 & 1.13 & 1,13 \\
P & 0,8 & 0,79 & 0,75 & 0,71 & 0,67 & 0,63 \\
\hline
\end{tabular}

2. Periode Finisher

Tabel 3. Susunan Formula dan Kandungan Nutrisi Ransum Periode Finisher

\begin{tabular}{lllllll}
\hline Komposisi pakan & R0a & R0b & R1 & R2 & R3 & R4 \\
\hline T.Jagung & & 52,4 & 52,4 & 52,4 & 52,4 & 52,4 \\
T.Ikan & & 8 & 8 & 8 & 8 & 8 \\
B.kedelai & & 22,1 & 22,1 & 22,1 & 22,1 & 22,1 \\
Dedak padi & & 12 & 9 & 6 & 3 & 0 \\
P. Kakao F & & 0 & 3 & 6 & 9 & 12 \\
Kapur & & 1 & 1 & 1 & 1 & 1 \\
Top Mix & & 1 & 1 & 1 & 1 & 1 \\
M. Nabati & & 3,5 & 3,5 & 3,5 & 3,5 & 3,5 \\
\hline Total & & 100 & 100 & 100 & 100 & 100 \\
\hline Kandungan Nutrisi & & & & & & \\
PK & 20 & 20 & 20,03 & 20,06 & 20,09 & 20.12 \\
EM & & 3054,48 & 3055,17 & 3055,85 & 3056,54 & 3057,22 \\
SK & $\max 5$ & 3,5 & 3,85 & 4,19 & 4,54 & 4,88 \\
LK & $\min 5$ & 4,34 & 4,06 & 3,79 & 3,51 & 3,24 \\
Ca & 1 & 1,04 & 1,04 & 1,03 & 1,03 & 1,03 \\
P & 0,6 & 0,71 & 0,67 & 0.63 & 0,59 & 0,55 \\
\hline K & & &
\end{tabular}

Ket : R0a: Pakan Komersial; R0b: 0\% pod kakao fermentasi dalam ransum; R1: 3\% pod kakao fermentasi dalam ransum; R2: $6 \%$ pod kakao fermentasi dalam ransum;R3: $9 \%$ pod kakao fermentasi dalam ransum;R4: $12 \%$ pod kakao fermentasi dalam ransum 


\section{Parameter Penelitian}

1. Bobot potong, bobot ayam yang dipuasakan 12 jam sebelum dilakukan penyembelihan, semua ayam ditimbang.

2. Bobot karkas $(\mathrm{g})$

3. Merupakan daging bersama tulang hasil pemotongan setelah dipisahkan kepala sampai batas pangkal leher, kaki sampai batas lutut, bulu, darah, serta isi rongga bagian dalam kecuali ginjal dan paru-paru. Karkas dipotong dengan diambil 2 ekor dari rata-rata berat badan di setiap plot.

4. Persentase karkas, diperoleh berdasarkan hasil perbandingan antara bobot karkas dan berat hidup ayam yang dinyatakan dalam persen.

5. Persentase lemak abdominal, diperoleh berdasarkan hasil perbandingan antara berat lemak abdominal dan berat hidup ayam yang dinyatakan dalam persen.

6. Bobot relatif organ dalam, yang terdiri atas :

- Hati (g/kg bobot potong)

- Empedal (g/kg bobot potong)

7. Panjang relatif organ pencernaan, yang terdiri atas :

- Usus halus yang terdiri dari duodenum, jejenum dan illeum $(\mathrm{cm})$

- Usus besar yang terdiri dari caecum dan rektum $(\mathrm{cm})$.

\section{Proses Pengamatan Karkas}

Pemotongan karkas dilakukan di tempat yang bersih, cukup air yang berasal dari sumber air berkualitas baik dan khusus. Cara pemotongan mengikuti persyaratan agama Islam, pengeluaran darah (bleeding) harus tuntas sehingga ayam benar-benar mati, sebelum pencabutan bulu ayam desuh (scalding) dengan temperatur dengan temperatur $52^{0}-60^{\circ} \mathrm{C}$ selama 3-5 menit, setelah dilakukan pencabutan bulu kemudian karkas ayam dicuci dengan air yang mengalir atau didinginkan (chilling) dengan temperatur $0-5^{0}$ (DSN, 2012).

Setelah penyembelihan, tubuh ayam broiler dipotong kepala dan kakinya, ditimbang berat karkas, berat hati, berat empedal, kemudian dipersenkan dan diukur panjang usus halus yang terdiri dari duodenum, jejenum dan illeum, serta usus besar yang terdiri dari caecum dan rektum. 


\section{HASIL DAN PEMBAHASAN}

Hasil penelitian bobot potong, bobot karkas, persentase karkas, bobot relatif empedal, panjang usus halus, panjang doudenum, panjang jejenum, panjang usus besar, panjang illeum, panjang caecum, panjang rektum, bobot relatif hati, bobot relatif lemak abdominal dari semua peubah dapat dilihat pada tabel rekapitulasi berikut.

Tabel 4. Rekapitulasi Hasil Penelitian Terhadap Karkas dan Bobot Relatif Organ Dalam

\begin{tabular}{|c|c|c|c|c|c|c|}
\hline \multirow{2}{*}{ Paramater Penelitian } & \multicolumn{6}{|c|}{ Perlakuan } \\
\hline & $\mathrm{R} 0 \mathrm{a}$ & $\mathrm{R} 0 \mathrm{~b}$ & R1 & $\mathrm{R} 2$ & R3 & $\mathrm{R} 4$ \\
\hline \multicolumn{7}{|l|}{1 Karkas } \\
\hline -Bobot Potong (g/ekor) & $\begin{array}{l}2263,7^{\mathrm{D}} \\
\pm 98,52\end{array}$ & $\begin{array}{l}1951,2^{\mathrm{C}} \\
\pm 73,52\end{array}$ & $\begin{array}{c}1870,0^{\mathrm{BC}} \\
\pm 44,9\end{array}$ & $\begin{array}{c}1822,5^{\mathrm{BC}} \\
\pm 68,0\end{array}$ & $\begin{array}{c}1668,7^{\mathrm{AB}} \\
\pm 35,4\end{array}$ & $\begin{array}{l}1601,7^{\mathrm{A}} \\
\pm 111,0\end{array}$ \\
\hline -Bobot Karkas (g/ekor) & $\begin{array}{l}1605,1^{\mathrm{D}} \\
\pm 72,07\end{array}$ & $\begin{array}{l}1374,5^{\mathrm{C}} \\
\pm 49,94\end{array}$ & $\begin{array}{l}1299,1^{\mathrm{BC}} \\
\pm 23,65\end{array}$ & $\begin{array}{c}1266,2^{\mathrm{BC}} \\
\pm 50,0\end{array}$ & $\begin{array}{c}1150,87^{\mathrm{AB}} \\
\pm 31,5\end{array}$ & $\begin{array}{l}1082,5^{\mathrm{A}} \\
\pm 59,58\end{array}$ \\
\hline -Persentase karkas (\%) & $\begin{array}{l}70,87^{\mathrm{B}} \\
\pm 0,386\end{array}$ & $\begin{array}{c}70,40^{\mathrm{B}} \\
\pm 0,244\end{array}$ & $\begin{array}{c}69,42^{\mathrm{AB}} \\
\pm 0,88\end{array}$ & $\begin{array}{c}69,42^{\mathrm{AB}} \\
\pm 0,25\end{array}$ & $\begin{array}{c}68,92^{\mathrm{AB}} \\
\pm 0,78\end{array}$ & $\begin{array}{c}67,62^{\mathrm{A}} \\
\pm 1,760\end{array}$ \\
\hline \multicolumn{7}{|l|}{2 Bobot Relatif Organ Dalam } \\
\hline -Empedal (g/kg bp) & $\begin{array}{c}13,8^{\mathrm{tn}} \pm \\
1,59\end{array}$ & $\begin{array}{c}15,2^{\mathrm{tn}} \pm \\
1,29\end{array}$ & $\begin{array}{c}14,7^{\mathrm{tn}} \pm \\
0,90\end{array}$ & $\begin{array}{c}14,2^{\mathrm{tn}} \pm \\
0,91\end{array}$ & $\begin{array}{c}14,4^{\mathrm{tn}} \pm \\
1,00\end{array}$ & $\begin{array}{c}13,8^{\mathrm{tn}} \pm \\
1,30\end{array}$ \\
\hline -Hati (g/kg bp) & $\begin{array}{c}24,0^{\operatorname{tn}} \pm \\
5,17\end{array}$ & $\begin{array}{c}24,2^{\mathrm{tn}} \pm \\
4,90\end{array}$ & $\begin{array}{c}25,2^{\mathrm{tn}} \pm \\
2,07\end{array}$ & $\begin{array}{c}23,4^{\mathrm{tn}} \pm \\
2,47\end{array}$ & $\begin{array}{c}24,6^{\mathrm{tn}} \pm \\
4,01\end{array}$ & $\begin{array}{c}22,9^{\mathrm{tn}} \pm \\
5,81\end{array}$ \\
\hline -Lemak abdominal (g/kg bp) & $\begin{array}{c}18,2^{\text {tn }} \pm \\
4,03\end{array}$ & $\begin{array}{c}18,0^{\mathrm{tn}} \pm \\
2,70\end{array}$ & $\begin{array}{c}15,5^{\mathrm{tn}} \pm \\
3,60\end{array}$ & $\begin{array}{c}15,5^{\mathrm{tn}} \pm \\
3,60\end{array}$ & $\begin{array}{c}14,3^{\text {tn }} \pm \\
5,22\end{array}$ & $\begin{array}{c}12,0^{\mathrm{tn}} \pm \\
2,39\end{array}$ \\
\hline $\begin{array}{cc}\text { Keterangan : } & \text { Notasi yang } \\
& \text { pengaruh yang } \\
& \text { tn }=\text { tidak berb } \\
& b p=\text { bobot pot }\end{array}$ & $\begin{array}{ll}e d a & p a \\
\text { eda } & \text { nya } \\
\text { yata }\end{array}$ & $\begin{array}{l}\text { baris yan } \\
P<0,01)\end{array}$ & sama & menunjukan & perlakuan & $\overline{\text { memberikan }}$ \\
\hline
\end{tabular}

\section{Karkas}

Karkas ayam broiler yang diamati dalam penelitian ini meliputi bobot potong, bobot karkas dan persentase karkas.

\section{Bobot Potong}

Bobot potong di peroleh dengan cara penimbangan bobot akhir ayam broiler setelah dipuasakan selama 12 jam. Rataan bobot potong tertinggi terdapat pada perlakuan R0a ( komersial) yaitu sebesar 2.263,75 g/ekor dan rataan bobot potong terendah terdapat pada 
perlakuan R4 (pakan yang mengandung 12\% pod kakao fermentasi Aspergillus niger dan 0\% dedak) yaitu sebesar 1.601,25 g/ekor (Tabel 4). Berdasarkan hasil analisis Ragam dapat diketahui bahwa perlakuan subtitusi dedak dengan pod kakao memberikan pengaruh berbeda sangat nyata $(\mathrm{P}<0,01)$ terhadap bobot potong.

Tabel 5. Rekapitulasi Penelitian terhadap Panjang Usus Halus dan Usus Besar.

\begin{tabular}{|c|c|c|c|c|c|c|}
\hline \multirow[t]{2}{*}{ Parameter Penelitian } & \multicolumn{6}{|c|}{ Perlakuan } \\
\hline & R0a & $\mathrm{R} 0 \mathrm{~b}$ & R1 & R2 & R3 & R4 \\
\hline 1. Panjang usus halus (cm) & $\begin{array}{c}167,87^{\mathrm{B}} \\
\pm 7,50\end{array}$ & $\begin{array}{c}172,87^{\mathrm{AB}} \\
\pm 9,8\end{array}$ & $\begin{array}{c}176,62^{\mathrm{AB}} \\
\pm 5,9\end{array}$ & $\begin{array}{c}182,62^{\mathrm{AB}} \\
\pm 12\end{array}$ & $\begin{array}{c}184,32^{\mathrm{AB}} \\
\pm 4,4\end{array}$ & $\begin{array}{c}189,62^{\mathrm{AB}} \\
\pm 4,9\end{array}$ \\
\hline -Doudenum (cm) & $\begin{array}{c}28,500^{\text {tn }} \\
\pm 4,45\end{array}$ & $\begin{array}{c}29,250^{\mathrm{tn}} \\
\pm 1,19\end{array}$ & $\begin{array}{c}29,375^{\mathrm{tn}} \\
\pm 2,14\end{array}$ & $\begin{array}{c}29,625^{\mathrm{tn}} \\
\pm 2,98\end{array}$ & $\begin{array}{c}30,250^{\mathrm{tn}} \\
\pm 1,50\end{array}$ & $\begin{array}{c}31,625^{\mathrm{tn}} \\
\pm 1,03\end{array}$ \\
\hline -Jejenum (cm) & $\begin{array}{c}70,75^{\mathrm{tn}} \pm \\
5,87\end{array}$ & $\begin{array}{c}71,50^{\operatorname{tn}} \pm \\
9,25\end{array}$ & $\begin{array}{c}73,00^{\mathrm{tn}} \pm \\
5,21\end{array}$ & $\begin{array}{c}74,62^{\text {tn }} \pm \\
5,66\end{array}$ & $\begin{array}{c}77,00^{\mathrm{tn}} \pm \\
4,10\end{array}$ & $\begin{array}{c}80,50^{\text {tn }} \pm \\
1,35\end{array}$ \\
\hline -Illeum $(\mathrm{cm})$ & $\begin{array}{c}68,625^{\mathrm{tn}} \\
\pm 6,74\end{array}$ & $\begin{array}{c}72,125^{\mathrm{tn}} \\
\pm 4,9\end{array}$ & $\begin{array}{c}74,250^{\mathrm{tn}} \\
\pm 7,18\end{array}$ & $\begin{array}{c}75,375^{\text {tn }} \pm \\
5,02\end{array}$ & $\begin{array}{c}76,875^{\text {tn }} \pm \\
4,4\end{array}$ & $\begin{array}{c}77,500^{\mathrm{tn}} \pm \\
2,9\end{array}$ \\
\hline 2. Panjang usus besar $(\mathrm{cm})$ & $\begin{array}{c}25,125^{\mathrm{B}} \\
\pm 0,85\end{array}$ & $\begin{array}{c}27,000^{\mathrm{AB}} \\
\quad \pm 1,8\end{array}$ & $\begin{array}{c}27,680^{\mathrm{AB}} \\
\pm 3,1\end{array}$ & $\begin{array}{c}28,430^{\mathrm{AB}} \pm \\
1,2\end{array}$ & $\begin{array}{c}29,190^{\mathrm{A}} \pm \\
1,60\end{array}$ & $\begin{array}{c}30,940^{\mathrm{A}} \pm \\
0,70\end{array}$ \\
\hline -Caecum $(\mathrm{cm}$ & $\begin{array}{c}17,00^{\operatorname{tn}} \pm \\
0,65\end{array}$ & $\begin{array}{c}18,00^{\operatorname{tn}} \pm \\
0,47\end{array}$ & $\begin{array}{c}18,43^{\mathrm{tn}} \pm \\
2,02\end{array}$ & $\begin{array}{c}18,68^{\mathrm{tn}} \pm \\
3,06\end{array}$ & $\begin{array}{c}19,19^{\mathrm{tn}} \pm \\
1,38\end{array}$ & $\begin{array}{c}19,94^{\mathrm{tn}} \pm \\
1,3\end{array}$ \\
\hline -Rektum (cm) & $\begin{array}{c}8,12^{\mathrm{tn}} \pm \\
0,53\end{array}$ & $\begin{array}{c}9,00^{\mathrm{tn}} \pm \\
1,29\end{array}$ & $\begin{array}{c}9,25^{\mathrm{tn}} \pm \\
3,12\end{array}$ & $\begin{array}{c}9,75^{\mathrm{tn}} \\
1,94\end{array}$ & $\begin{array}{c}10,00^{\mathrm{tn}} \pm \\
1,78\end{array}$ & $\begin{array}{c}11,00^{\mathrm{tn}} \pm \\
1,00\end{array}$ \\
\hline $\begin{aligned} \text { gan : Notasi ya } & \text { pengaruh } \\
& \text { th }=\text { tidak }\end{aligned}$ & $\begin{array}{l}\text { berbeda } \\
\text { berbeda } \\
\text { eda nyata }\end{array}$ & $\begin{array}{l}a d a b \\
\operatorname{ata}(P\end{array}$ & yang & тепи & perlakua & memberikan \\
\hline
\end{tabular}

Selanjutnya untuk mengetahui perbedaan antar perlakuan dilakukan uji Tukey. Dari hasil uji Tukey diperoleh perlakuan R0a memberi nilai rataan yang berbeda terhadap perlakuan R0b, R1, R2, R3, R4. Pada perlakuan subtitusi, bobot potong terbesar diperoleh dari perlakuan R0b yaitu sebesar 1951,25, namun memberikan nilai rataan yang tidak berbeda terhadap perlakuan $\mathrm{R} 1$ dan $\mathrm{R} 2$, tetapi memberikan nilai rataan yang berbeda menurun terhadap R3 dan R4. Subtitusi dedak padi oleh pod kakao baik pada perlakuan R0b, R1 maupun R2 menghasilkan rataan bobot potong yang tinggi yaitu 1951,25, 1870, 1822 . Namun demikian semua perlakuan subtitusi yang digunakan menghasilkan rataan bobot potong yang lebih kecil dari perlakuan R0a (kontrol).

Hasil penelitian didapat semakin tinggi tingkat penggunaan subtitusi dedak padi oleh pod kakao maka bobot potong semakin menurun, hal ini karena adanya zat anti nutrisi yang terdapat pada pod kakao yaitu theobromin yang dapat menurunkan bobot potong apabila terus diberikan pada ransum ayam broiler. Hal ini sesuai dengan pernyataan Tarka et al. (1993) 
yang menyatakan bahwa faktor pembatas pemberian pod kakao sebagai pakan ternak adalah terdapatnya anti nutrisi theobromin pada pod kakao. Theobromin merupakan alkolid tidak berbahaya yang dapat dirusak dengan pemanasan dan pengeringan, tetapi pemberian pakan yang mengandung theobromin secara terus menerus dapat menurunkan pertumbuhan. Bobot potong sangat erat kaitanya dengan pertambahan bobot badan sesuai dengan pernyataan Soeparno (1994) yang menyatakan bahwa pertambahan bobot badan sangat mempengaruhi bobot potong dan pernyataan Nataadmidjaya, et al (1995), bahwa pertambahan bobot badan juga dapat dipengaruhi oleh bahan pakan penyusun ransum. Tingginya serat kasar dalam ransum dapat mengurangi efisiensi penyerapan ransum hal ini sesuai dengan pernyataan Siregar dan Sabrani (1970) yang menyatakan bahwa serat kasar yang tinggi dapat mengurangi efisiensi penggunaan nutrisi lain, sebaliknya apabila serat kasar dalam ransum terlalu rendah, mengakibatkan ransum tidak tercerna dengan baik.

\section{Bobot Karkas}

Bobot karkas merupakan bobot tubuh ayam yang telah disembelih setelah dipisahkan darah, bulu, kepala sampai batas pangkal leher, kaki sampai batas lutut dan organ dalam kecuali ginjal dan paru-paru (Murtidjo, 1992). Rataan bobot karkas tertinggi yang diperoleh dari hasil penelitian pada perlakuan R0a sebesar 1.605,125 g dan terendah diperoleh dari perlakuan R4 sebesar 1.082,5 g (Tabel 4). Berdasarkan hasil analisis ragam dapat diketahui bahwa subtitusi dedak oleh pod kakao memeberikan pengaruh berbeda sangat nyata $(\mathrm{P}<0,01)$ terhadap bobot karkas.

Perbedaan antar perlakuan dilakukan uji Tukey. Dari hasil uji Tukey diperoleh perlakuan R0a berbeda nyata terhadap perlakuan R0b, R1, R2, R3, R4. Pada perlakuan subtitusi, bobot karkas terbesar diperoleh dari perlakuan R0b yaitu sebesar 1374,5, namun memberikan nilai rataan yang tidak berbeda terhadap perlakuan R1 dan R2, tetapi memberikan nilai rataan yang berbeda menurun terhadap R3 dan R4 . Subtitusi dedak padi oleh pod kakao baik pada perlakuan R0b, R1 maupun R2 menghasilkan rataan bobot karkas yang tinggi yaitu 1374,5, 1299,12, 1266,25. Namun demikian semua perlakuan subtitusi yang digunakan menghasilkan rataan bobot potong yang lebih kecil dari perlakuan R0a (kontrol).

Hasil penelitian didapat semakin tinggi tingkat penggunaan subtitusi dedak padi oleh pod kakao maka bobot potong semakin menurun, adapun yang menjadi penyebab menurunnya bobot karkas dari setiap perlakuan karena faktor pakan. Hal ini sesuai dengan pernyatann Grey et al. (1982) yang menyatakan bahwa faktor-faktor yang mempengaruhi 
bobot karkas tidak hanya jenis kelamin, umur dan bobot badan tetapi ada beberapa faktorfaktor yang dapat mempengaruhi karkas diantaranya adalah strain, pakan, manajemen dan lingkungan. Hal ini juga didukung oleh pernyataan Tarka et al. (1993) yang menyatakan bahwa faktor pembatas pemberian pod kakao sebagai pakan ternak adalah terdapatnya anti nutrisi theobromin pada pod kakao. Theobromin merupakan alkolid tidak berbahaya yang dapat dirusak dengan pemanasan dan pengeringan, tetapi pemberian pakan yang mengandung theobromin secara terus menerus dapat menurunkan pertumbuhan sehingga dapat menurunkan bobot karkas.

\section{Persentase Karkas}

Persentase karkas diperoleh dari bobot karkas dibagi dengan bobot potong dikali 100 persen. Persentase karkas tertinggi yang diperoleh pada perlakuan R0a yaitu sebesar 70,875 $\%$ dan terendah pada perlakuan R4 yaitu sebesar 67,625 \% (Tabel 4). Berdasarkan hasil analisis ragam dapat diketahui bahwa subtitusi dedak oleh pod kakao memberikan pengaruh berbeda sangat nyata $(\mathrm{P}<0,01)$ terhadap persentase karkas.

Perbedaan antar perlakuan dilakukan dengan uji Tukey. Dari hasil uji Tukey didapat rataan persentase karkas perlakuan R0a (kontrol) memberikan nilai rataan yang tidak berbeda terhadap perlakuan R0b, R1, R2, dan R3, namun memberikan nilai rataan yang berbeda terhadap perlakuan R4. Pada perlakuan subtitusi R0b, R1, R2 dan R3 memberikan nilai rataan yang tidak berbeda terhadap perlakuan R0a, namun memberikan nilai rataan yang berbeda dengan R4. Subtitusi dedak padi oleh pod kakao masih dapat digunakan sampai tingkat substitusi $25 \%$ dedak padi $+75 \%$ pod kakao (perlakuan R3) terhadap persentase karkas.

Persentase karkas dipengaruhi oleh bobot tubuh dan juga produksi karkas. Hal ini sesuai dengan pernyataan Murtidjo (1987) yang menyatakan bahwa persentase karkas merupakan faktor yang penting untuk menilai produk ternak, karena produksi erat hubungannya dengan bobot hidup, dimana semakin bertambah bobot hidup maka produksi karkas semakin meningkat. Hal ini juga sesuai dengan pernyataan Ahmat dan Herman (1992) yang menyatakan bahwa ayam yang bobot tubuhnya tinggi akan menghasilkan persentase karkas yang tinggi, sebaliknya ayam yang bobot tubuhnya rendah akan menghasilkan persentase yang rendah. 


\section{Bobot Relatif Organ Dalam}

Bobot relatif organ dalam di peroleh dari penimbangan berat empedal, hati dan lemak abdominal.

\section{Empedal}

Bobot relatif empedal diperoleh dari berat empedal dibagi dengan bobot potong. bobot relatif empedal tertinggi yang diperoleh pada perlakuan R0b yaitu sebesar $15,2 \mathrm{~g} / \mathrm{kg}$ bobot potong dan terendah pada perlakuan R0a dan R4 yaitu sebesar 13,8 g/kg bobot potong (Tabel 4). Berdasarkan analisis ragam diketahui pengaruh subtitusi dedak oleh pod kakao tidak berpengaruh nyata terhadap bobot relatif empedal. Dari hasil penelitian didapat bahwa berat rempela antar perlakuan tidak berbeda nyata karena berat empedal dipengaruhi oleh ransum dimana pada saat penelitian setiap perlakuan mendapat ransum yang berbeda. Hal ini sesuai dengan pernyataan Prilyana (1984) yang menyatakan bahwa bobot empedal dipengaruhi oleh umur, bobot badan dan makanan. Pemberian makanan yang lebih banyak akan menyebabkan aktivitas empedal lebih besar untuk mencerna makanan sehingga urat daging empedal menjadi lebih tebal dan memperbesar ukuran empedal.

\section{Hati}

Bobot relatif hati diperoleh dari bobot hati dibagi dengan bobot potong. bobot relatif hati tertinggi yang diperoleh pada perlakuan R1 yaitu sebesar $25,2 \mathrm{~g} / \mathrm{kg}$ bobot potong dan terendah pada perlakuan R4 yaitu sebesar 22,9 g/kg bobot potong (Tabel 4). Berdasarkan analisis ragam diketahui pengaruh subtitusi dedak padi oleh pod kakao dalam ransum tidak berpengaruh nyata terhadap bobot relatif hati. Hal tersebut menunjukkan bahwa ransum perlakuan tidak mengandung zat yang bersifat racun yang dapat menyebabkan kerja hati menjadi berlebih dan persentase hati masih berkisar normal. Salah satu fungsi hati adalah detoksifikasi racun dan apabila terjadi kelainan pada hati ditunjukkan dengan adanya pembesaran dan pengecilan hati (Ressang, 1994).

\section{Lemak Abdominal}

Lemak abdominal diperoleh dari hasil penimbangan lemak yang terdapat disekitar rongga perut dan sekitar kloaka yang dihitungkan dalam satuan ( $\mathrm{gr} / \mathrm{kg}$ bobot potong). bobot relatif lemak abdominal tertinggi yang diperoleh pada perlakuan R0a yaitu sebesar $18,2 \mathrm{~g} / \mathrm{kg}$ bobot potong dan terendah pada perlakuan R4 yaitu sebesar $12 \mathrm{~g} / \mathrm{kg}$ bobot potong ( tabel 4). 
Berdasarkan analisis ragam diketahui subtitusi dedak padi dengan pod kakao dalam ransum tidak berpengaruh nyata terhadap lemak abdominal. Tidak adanya pengaruh yang nyata terhadap lemak abdominal ayam broiler antar perlakuan dipengaruhi oleh kandungan nutrisi ransum yang hampir sama pada tiap perlakuan. Hal ini sesuai dengan pernyataan Soeparno (1994), yang menyatakan bahwa nutrisi merupakan faktor terpenting yang mempengaruhi komposisi karkas terutama terhadap proporsi lemak. Hal ini ditambah dengan pernyataan Komot (1984), menyatakan perlemakan tubuh diakibatkan dari konsumsi energi pakan yang berlebih yang akan disimpan didalam jaringan tubuh yaitu pada sub kutan dan abdominalis. Hal ini sesuai dengan pernyataan Wahyu (1997), yang menyatakan bahwa sebagian besar digunakan untuk mempertahankan hidup pokok meliputi metabolisme dan aktifitas normal, tetapi kelebihan energi dapat menyebabkan penimbunan lemak dan salah satu cara mengurangi perlemakan adalah memvariasikan nutrisi ransum terutama energi dan protein.

\section{Panjang Usus}

Panjang usus diperoleh dari pengukuran panjang usus halus yang terdiri dari panjang duodenum, jejenum dan illeum. Panjang usus besar diperoleh dari pengukuran panjang caecum dan rektum.

\section{Panjang Usus Halus}

Panjang usus halus diperoleh dari ujung empedal sampai batas pangkal caecum. Panjang usus halus tertinggi diperoleh pada perlakuan R4 yaitu 189,6 $\mathrm{cm}$ dan terendah pada perlakuan R0a yaitu 167,8 cm (Tabel 5). Dari hasil penelitian dilihat rataan panjang usus halus sekitar 167,8-189,6 cm.

Perbedaan antar perlakuan dilakukan dengan uji Tukey. Dari hasil Tukey didapat rataan panjang usus halus perlakuan R0a (kontrol) memberikan nilai rataan yang tidak berbeda terhadap R0b, R1, R2,dan R3, namun memberikan nilai rataan yang berbeda terhadap perlakuan R4. Pada perlakuan subtitusi R0b, R1, R2 dan R3 memberikan nilai rataan yang tidak berbeda terhadap perlakuan R0a, namun memberikan nilai rataan yang berbeda dengan R4. Subtitusi dedak padi oleh pod kakao masih dapat digunakan samapai R3 terhadap usus halus.

Hasil penelitian menunjukkan semakin tinggi tingkat subtitusi dedak padi oleh pod kakao maka panjang usus halus semakin tinggi. Ini disebabkan oleh semakin tinggi tingkat 
subtitusi serat kasar dalam ransum semakin tinggi. Hal ini sesuai dengan pernyataan Syamsuhaidi (1997) yang menyatakan peningkatan kadar serat kasar dalam ransum, maka semakin lambat laju pencernaan dan penyerapan zat makanan. Anggorodi (1994) juga menyatakan bahwa semakin tinggi kandungan serat kasar dalam suatu bahan pakan maka semakin rendah daya cerna pakan tersebut. Aksos (1993) menyatakan bahwa usus halus yaitu usus tempat terjadinya pencernaan dan penyerapan pakan. Selaput lendir usus halus mempunyai tempat yang lembut dan menonjol seperti jari. Fungsi usus halus selain sebagai penggerak aliran pakan dalam usus juga untuk meningkatkan penyerapan pakan.

\section{Duodenum (cm)}

Panjang douedenum diperoleh dari pengukuran ujung empedal sampai panjang usus yang mengitai pankreas. rataan panjang duodenum tertinggi yang di peroleh pada perlakuan $\mathrm{R} 4$ yaitu $31,625 \mathrm{~cm}$ dan terendah pada perlakuan R0a yaitu sebesar 28,5 cm (Tabel5). Berdasarkan analisis ragam diketahui subtitusi dedak dengan pod kakao tidak berpengaruh nyata terhadap panjang duodenum. Perbedaan antara setiap perlakuan terjadi karena semakin tinggi kandungan serat kasar dari suatu ransum maka semakin rendah daya cerna terhadap ransum tersebut. Hal ini sesuai dengan pernyataan Anggorodi (1994), menyatakan bahwa semakin tinggi kandungan serat kasar dalam suatu bahan pakan maka semakin rendah daya cerna pakan tersebut.

Usus halus merupakan tempat terjadinya pencernaan dan penyerapan pakan sehingga dapat diserap yang bisa mempengaruhi terhadap panjang usus halus terutama duodenum. Hal ini sesuai dengan pernyataan Aksos (1993) yang menyatakan bahwa usus halus yaitu usus tempat terjadinya pencernaan dan penyerapan pakan. Selaput lendir usus halus mempunyai tempat yang lembut dan menonjol seperti jari. Fungsi usus halus selain sebagai penggerakan aliran pakan dalam usus juga untuk meningkatkan penyerapan pakan.

Hasil penelitian menunjukkan bahwa rataan duodenum berkisar 28,5-31,625 cm. Hal ini sesuai dengan pernyataan Widianingsih (2008) yang menyatakan bahwa panjang duodenum berkisar 29,45-33,15 cm.

\section{Jejenum (cm)}

Panjang jejenum diproleh dari ujung doudenum sampai batas michael diventriculum. panjang jejenum tertinggi yang diperoleh pada perlakuan $\mathrm{R} 4$ yaitu $80,5 \mathrm{~cm}$ dan terendah 
pada perlakuan R0a yaitu 70,75 cm (Tabel 5). Dari hasil penelitian dilihat rataan jejenum sekitar 70,5-80,75 $\mathrm{cm}$. Berdasarkan analisis ragam diketahui pengaruh subtitusi dedak oleh pod kakao dalam ransum tidak berpengaruh nyata terhadap panjang jejenum. Dalam penelitian terjadi perbedaan panjang jejenum dari setiap perlakuan disebabkan karena objek dari setiap perlakuan menyerap pakan berbeda-beda yang menyebabkan panjang jejenum berbeda antar setiap perlakuan. Hal ini sesuai dengan pernyataan Syamsuhaidi (1997) yang menyatakan bahwa peningkatan kadar serat kasar dalam ransum cenderung akan memperpanjang usus. Semakin tinggi serat kasar dalam ransum, maka semakin lambat laju pencernaan dan penyerapan zat makanan.

Hasil penelitian dilihat rataan jejenum sekitar 70,5-80,75 cm. Hal ini sesuai dengan pernyataan Widianingsih (2008) yang menyatakan bahwa panjang jejenum $61,15-82,05$ $\mathrm{cm}$.

\section{Ileum (cm)}

Panjang illeum diperoleh dari michael diventriculum sampai batas pangkal caecum. Panjang illeum tertinggi yang diperoleh pada perlakuan R4 yaitu 77,5 cm dan terendah pada perlakuan R0a yaitu 68,625 cm (Tabel 5). Berdasarkan analisis ragam diketahui pengaruh subtitusi dedak dengan pod kakao dalam ransum tidak berpengaruh nyata terhadap panjang illeum. Hal ini terjadi karena ransum yang diberikan antar perlakuan berbeda dan penyerapan pakan rendah karena ransum yang diberikan mengandung serat kasar yang tinggi sehingga ransum yang diserap rendah. Hal ini sesuai dengan pernyatan Syamsuhaidi (1997) yang menyatakan bahwa peningkatan kadar serat kasar dalam ransum cenderung akan memperpanjang usus. Semakin tinggi serat kasar dalam ransum, maka semakin lambat laju pencernaan dan penyerapan zat makanan.

\section{Panjang Usus Besar}

Panjang usus besar diperoleh dari total panjang caecum dan total panjang rektum. panjang usus besar tertinggi diperoleh pada perlakuan R4 yaitu $30,93 \mathrm{~cm}$ dan terendah pada perlakuan R0a yaitu 25,11 cm (Tabel 5). Dari hasil penelitian dilihat rataan panjang usus besar sekitar 25,11-30,93 cm.

Perbedaan antar perlakuan dilakukan dengan uji Tukey. Dari hasil uji Tukey didapat rataan panjang usus besar perlakuan Roa (kontrol) memberikan nilai rataan yang tidak berbeda terhadap R0b, R1 dan R2, namun memberikan nilai rataan yang berbeda terhadap R3 
dan R4. Pada perlakuan subtitusi R0b, R1 dan R2 memberikan nilai rataan yang tidak berbeda terhadap perlakuan R0a, tetapi memberikan nilai rataan yang berbeda terhadap R3 dan R4. Subtitusi dedak padi oleh pod kakao masih dapat digunakan sampai R2 terhadap panjang usus besar.

Serat kasar dalam ransum akan mempengaruhi panjang usus itu sendiri, hal ini sesuai dengan pernyataan Amrullah (2004) yang menyatakan bahwa ukuran panjang, tebal, bobot berbagi saluran pencernaan dapat berubah selama perkembangan yang dipengaruhi oleh ransum. Ransum dengan kandungan serat kasar yang tinggi dapat memperberat, memperpanjang dan mempertebal berbagai saluran pencernaan.

\section{Caecum (cm)}

Panjang caecum diukur dari pangkal sampai ujung caecum. Panjang caecum tertinggi yang di peroleh pada perlakuan R4 yaitu 19,94 cm dan terendah pada perlakuan R0a yaitu 17 cm ( Tabel 5). Berdasarkan analisi ragam diketahui pengaruh subtitusi dedak padi dengan pod kakao fermentasi Aspergillus niger dalam ransum tidak berpengaruh nyata terhadap panjang caecum. Dari hasil penelitian didapat bahwa rataan panjang caecum 17-19,94 cm. Hasil yang didapat dari penelitian tidak sesuai dengan pernyatataa Nickle et al., (1977) yang menyatakan bahwa bahwa panjang caecum unggas normal berkisar antara 12-25 cm dan panjang caecum akan cenderung meningkat dengan kandungan serat kasar dalam ransum.

\section{Rektum (cm)}

Panjang rektum diperoleh dari pangkal usus buntu sampai batas usus besar. panjang rektum tertinggi yang di peroleh pada perlakuan $\mathrm{R} 4$ yaitu $11 \mathrm{~cm}$ dan terendah pada perlakuan R0a yaitu 8,125 cm (Tabel 5). Berdasarkan analisis ragam diketahui pengaruh subtitusi dedak padi dengan pod kakao dalam ransum tidak berpengaruh nyata terhadap panjang rektum. Dari hasil penelitian didapat bahwa panjang rektum antar perlakuan tidak berbeda nyata karena jenis ransum yang berbeda dan kandungan serat kasarnya berbeda. Hal ini sesuai dengan pernyataan Amrullah (2004) yang menyatakan bahwa ukuran panjang, tebal dan bobot berbagai saluran pencernaan dapat berubah selama proses perkembangan yang dipengaruhi oleh ransum. Ransum dengan kandungan serat kasar yang tinggi dapat memperberat, memperpanjang dan mempertebal berbagai saluran pencernaan. Perubahan ini diikuti dengan jumlah vili usus atau jonjot dan kemampuan sekresi enzin-enzim pencernaan.

Hasil penelitian didapat bahwa panjang rektum $8,125-11 \mathrm{~cm}$. Hal ini sesuai dengan pernyataan Amrullah (2004) yang menyatakan bahwa panjang rektum yang dimiliki ayam 
dewasa berkisar dari $8-10 \mathrm{~cm}$ dengan diameter dua kali lipat usus halus. Hal ini juga didukung oleh pernyataan North (1990) yang menyatakan bahwa ayam mempunyai usus besar yang pendek hanya $10 \mathrm{~cm}$.

\section{KESIMPULAN}

Berdasarkan hasil penelitian dapat disimpulkan bahwa semakin tinggi tingkat subtitusi dedak padi oleh pod kakao fermentasi dalam ransum menurunkan bobot potong, bobot karkas, persentase karkas dan meningkatkan panjang usus halus dan usus besar. Tingkat optimum subtitusi dedak padi oleh pod kakao yang difermentasi Aspergillus niger dalam ransum adalah sebanyak 50\%. Tingkat subtitusi dedak padi oleh pod kakao tidak memberikan pengaruh terhadap panjang duodenum, jejenum, illeum, caecum, rektum, bobot relatif hati, empedal dan lemak abdominal.

\section{DAFTAR PUSTAKA}

Akoso, B.T.1993. Manual Kesehatan Unggas. Kanisius. Yogyakarta.

Amrullah, I. K. 2003. Nutrisi Ayam Broiler. Lembaga Satu Gunungbudi. Bogor.

Anggorodi, R. 1985. Ilmu Makanan Ternak Unggas. UI-press. Jakarta.

Anggorodi, R.1994. Nutrisi Aneka Unggas. Gramedia Pustaka Utama. Jakarta.

BPSSUMUT. 2010. Luas dan Produksi Tanaman Kakao. Tersedia di http luas dan produksi kakao. Diakses tanggal tanggal 10 April 2012 Pukul 13.00 WIB. Medan.

Darwin, A.A., E. Sukara, T. Tedja, dan R. Purnawati. 1988. Biokonversi Limbah Lignoselulosa oleh Trichoderma varideae dan Aspergillus niger. Lab. Bioindustri, PAU-Bioteknologi, IPB. Bogor.

Dewan Standarisasi Nasional DSN (2012). Karkas Ayam Pedaging. Pusat Standarisasi-LIPI. Jakarta.

Grey, F. C., D. Robinson and J. M, Jones. 1982. Effect of age and sex on the eviscerated yield, muscle and edibel offal at a commercial broiler strains. British Poultry. Sci. 23: 289-298

Komot, H. 1984. Tinjauan Mengenai Perlemakan Beberapa Faktor yang Dapat Mempengaruhi Penimbunan pada Ayam Broiler. Thesis Fakultas Peternakan UNPAD. Bandung

Laboratorium Ilmu Nutrisi dan Pakan Ternak, 2010. Hasil Analisis Kulit Kakao Fermentasi. Program Studi Perternakan, FP USU. Medan.

Loka Penelitian Kambing Potong, 2011. Analisis Laboratorium “ Kulit Kakao Fermentasi”. Pusat Penelitian dan Pengembangan Perternakan. Sei Putih.

Murtidjo, B.A. 1987. Pedoman Meramu Pakan Unggas. Kanisius. Yogyakarta.

Murtidjo, B.A. 1992. Pedoman Berternak Ayam Broiler. Kanisius. Jakarta.

Nataamidjaya, A.G., K. Dwwiyanto dan S.N. Jarmani. 1995. Pendugaan Kebutuhan Pokok Nutrisi Unggas Plasm Nutfah Sistem Free Chise Feeding-Preceeding Seminar Nasional Sains dan Teknologi Peternakan. Balai Penelitian Ternak Ciawi. Bogor. 
Nikkel, et al. (1977). Anatomy of Domestic Bird. Verlag. Paul Parey. Berlin.

North, M. O. dan D. D. Bell. 1990. Commercial Chicken Production Manual. 4th Edition. Van Nostrad Rein Hold. New York.

Prilyana, J. D. 1984. Pengaruh Pembatasan Pemberian Ransum Terhadap Persentase Karkas, Lemak Abdominal, Lemak Daging Paha dan Bagian Giblet Ayam Pedaging. Disertasi. Program Pascasarjana. Institut Pertanian Bogor. Bogor.

Ressang, A. A. 1963. Patologi Khusus Veteriner. Edisi II. N. V. Percetakan Bali. Denpasar.

Saono, S., 1988. Pemanfaatan Jasad Renik dalam Pengolahan Hasil Sampingan/ Sisa-sisa Produksi Pertanian. LIPI. Jakarta.

Siregar, A., 1996. Budidaya Coklat. Kanisius. Jakarta.

Siregar, Z., 2009. Pemanfaatan Hasil Sampingan Perkebunan dengan Penambahan Mineral dan Hidrolisat Bulu Ayam. Universitas Sumatera Utara. Medan.

Siregar.A.P dan M. Sabrani. 1990. Teknik Modern Berternak Ayam.Jakarta. Yasaguna. Jakarta

Soeparno, 1994. Ilmu dan Tekhnologi Daging. Gadjah Mada University Press. Yogyakarta.

Syamsuhaidi. 1997. Pembangunan Duckweed (Family Lemnaceae) sebagai Pakan Serat Sumber Protein dalam Ransum Ayam Pedaging. Disertasi. Program Pascasarjana Institut Pertanian Bogor. Bogor.

Tarka, S.M., B. L. Zoumas and G.A. Trout. 1998. Examination of effect cocoa shell with theobromin in lomb. Nutrition Report International.

Wahyu, J., 1992. Ilmu Nutrisi Unggas. UGM-Press. Yogyakarta.

Widianingsih, M, N. 2008. Persentase Organ Dalam Broiler yang Diberikan Ransum Crumble Berperekat Onggok, Bentonif dan Tapioka. Skripsi. IPB. 